\title{
Proposed Bylaws Revision of SEES
}

Editor's Note: The proposed Bylaws will be voted upon at the 1980 ALA Annual Conference.

\section{Slavic and East European Section}

A Section of THE

association of College and Research Libraries AMERICAN Library ASSOCIATION BYLAWS

\section{Article I. Name}

The name of this organization shall be the Slavic and East European Section of the Association of College and Research Libraries, a division of the American Library Association.

\section{Article II. Object}

Sec. 1. This section shall represent librarians and other persons whose work or interest is related to Slavic and East European studies. It will act for ACRL in cooperation with other professional groups that require special knowledge of the area and languages of the Soviet Union and Eastern Europe.

Sec. 2. The Slavic and East European Section's responsibilities are:

(a) To advance the interests in Slavic and East European Librarianship.

(b) To promote library instruction, research and publication in the field of Slavic and East European Librarianship.

(c) To review problems of access and control of Slavic and East European materials and recommend improvements in their processing

\section{Article III. Membership}

Any member of the Association of College and Research Libraries may select membership in this Section by payment of dues to the American Library Association and any additional dues required for membership in ACRL and its sections. Every member has the right to vote. Any personal member is eligible to hold office.

\section{Article IV. Officers}

Sec. 1. Officers. The officers of this Section shall be a chairperson, a vice-chairperson/ chairperson-elect, the immediate past chairperson, a secretary and a member at large.

Sec. 2. Terms. All officers shall serve until the adjoumment of the annual meeting at which their successors are announced. In case of a vacancy in any office, except chairperson, the replacement will be appointed by the chairperson.

(a) Chairperson. The chairperson shall serve for one year.

(b) Vice-chairperson. The chairperson-elect shall serve as vice-chairperson for one year. At its expiration, or earlier, in case of a vacancy in the office of chairperson, the vice-chairperson succeeds to the office of chairperson.

(c) Secretary. The secretary shall serve for a term of three years.

(d) Member at large. The member at large shall serve for a term of one year.

\section{Article V. Executive Committee}

Sec. 1. Composition. The Executive Committee shall consist of the officers and chairpersons of committees

Sec. 2. Powers and Duties. The Executive Committee shall have the authority to conduct the business of the Section provided that none of its acts shall conflict with or modify any action taken by ACRL and ALA.

Sec. 3. Meetings. Regular meetings of the Executive Committee shall be held at the time and place of the Annual Conference and Midwinter Meeting of the American Library Association. Special meetings may be called at the discretion of the chairperson.

Sec. 4. Quorum. A majority of the members constitute a quorum at any meeting of the Executive Committee.

\section{Article VI. Committees}

Sec. 1. Authorization and Discontinuance. Committees of the Section may be authorized or discontinued by the chairperson with the approval of the Executive Committee.

Sec. 2. Standing Committees. Standing committees may be established to consider matters of the Section that require continuity of attention by the members. When such a committee is established, its function, name, and size shall be determined. Members of standing committees shall be appointed for terms of two years and may be reappointed for a second but not a third consecutive term. Appointments shall be made in such a manner as to provide continuity in membership.

Sec. 3. Special Committees. Special (ad hoc) committees may be established at any time for the performance of a particular assignment. No such committee may be continued beyond two years without review and reapproval by the Executive Committee

Sec. 4. Appointments. The-vice-chairperson/ chairperson-elect shall appoint committee members to fill the vacancies due to occur during his/her term as chairperson. He/she may request each committee to elect its own chairperson or may name the chairperson of each committee.

Sec. 5. Reporting. Committee chairperson shall make reports to the Executive Committee at its regular meetings. 
Article VII. Meetings

Sec. 1. The regular business meeting of the Section shall be held at the time and place of the Annual Conference of the American Library Association.

Sec. 2. Ten members shall constitute a quorum at the meeting.

\section{Article VIII. Nominations and Elections}

Sec. 1. Nominations. The vice-chairperson/ chairperson-elect of the Section, with the approval of the chairperson, shall appoint a Nominating Committee of at least three personal members of the Section. This committee shall present at least two candidates for each of the offices of the chairperson-elect, of the member at large, and, every third year, of secretary. Each candidate presented must have consented to the candidacy in writing and must be a member in good standing at the time of nomination.

Sec. 2. Elections. Elections shall be conducted by mail ballot in accordance with the procedures and deadlines established by the American $\mathrm{Li}$ brary Association. For each office, the candidate receiving the largest number of votes cast shall be elected. In case of a tie vote, the successful candidate shall be determined by lot. Candidates elected shall be reported at the annual meeting.
Article IX. General Provisions

Whenever these Bylaws make no specific provisions, the organization of and the procedure in this Section shall correspond to that set forth in the Bylaws of ACRL.

\section{Article X. Amendments}

Sec. 1. Proposals. Amendments to these Bylaws may be proposed in writing to the membership of the Section by the Executive Committee, or a committee appointed for this purpose, or by any five members. Proposals originating from the membership shall be filed with the secretary at least three months before the annual meeting.

Sec. 2. Voting. A copy of any proposed amendment shall be mailed by the secretary of the Section to each member at least thirty days before the annual meeting or shall be announced in College \& Research Libraries News in an issue prior to the annual meeting. A plurality vote of the members present and voting at an annual meeting or casting ballots in a mail vote shall carry a proposed amendment.

(Bylaws Revision Committee: Edward Kasinec, Harvard University; Andrew Turchyn, Indiana University; Oleg Kudryk, chairperson, Indiana University.)

\section{Pre-Publication Catalog}

This catalog is the only one of its kind in our industry and by using it a librarian can MONITOR University Press Publishing. The catalog is produced twice a year in a revised. updated form. It's still another example of how we attempt to anticipate a library's needs and to offer services accordingly.

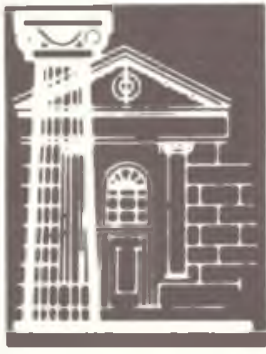

For more information on this plan, call us on our

\section{Toll-Free WATS Line 1-800-325-8833}

Missouri Customers Call Collect:

0-314-739-3100 Ask for Mr. Lesser

"19 Years of Service to College and University Libraries"

Midwest Library Service

11443 St.Charles Rock Rd., Bridgeton, Mo. 63044 